\title{
Dossiê "Recepção: Nietzsche no Brasil - núcleo histórico, parte IV"
}

\section{Nota Preliminar}

\section{Dossiê "Nietzsche no Brasil (1933-1943): da ascensão do nacional-socialismo ao Grande Reich Alemão" (Parte I: 1933-1939).}

A começar pelo ensaio "Nietzsche, fonte de Hitler" (publicado no ano de 1933 em Porto Alegre) e tendo como delimitação o artigo "Ideias de Nietzsche" (escrito em 1943 no Rio de Janeiro) a presente pesquisa tem como foco mostrar como o pensamento do filósofo alemão foi recebido no Brasil no período compreendido entre ascensão do nacional-socialismo e o Grande Reich Alemão. Investigação que busca concentrar-se em jornais e revistas dos estados do Rio Grande do Sul, Paraná, São Paulo, Rio de Janeiro e Pernambuco, ela permite constatar a complexidade das abordagens do pensamento nietzschiano entre nós, em particular por nomes expressivos no meio intelectual brasileiro como Otto Maria Carpeaux, Euryalo Cannabrava, José Lins do Rego e Edmundo Moniz. Compreendido de modo geral como um "gênio singular", diversos são os autores que procuram enfatizar que Nietzsche não poderia ser tomado nem como baluarte revolucionário de esquerda nem como expoente reacionário de direita, sendo que suas ideias serviriam muito mais para explicar 
a ruína dos valores da velha civilização europeia. A presente edição dos Cadernos Nietzsche traz a público os primeiros nove textos desta pesquisa, os quais foram publicados originalmente nas revistas $O$ Globo e Carioca e nos jornais Correio da Manhã, Gazeta de Notícias, Correio Paulistano e Diário de Pernambuco.

Luís Rubira e Fabiano Pinto

Organizadores

126 Cad. Nietzsche, Guarulhos/Porto Seguro, v.37, n.2, p. 125-126, julho/setembro, 2016. 